\title{
PERAN BIDAN DALAM KEWENANGAN TINDAKAN EPISIOTOMI YANG DIPERLUAS PADA PRAKTEK SWASTA MANDIRI DAN KLINIK BERSALIN
}

(Studi Kasus Bidan Mandiri di Kabupaten Tangerang)

\author{
Hadiwijaya, Agnes Widanti dan Agus H. Rahim \\ Hadiwijaya_2006@yahoo.com \\ Magister Hukum Kesehatan \\ Universitas Katolik Soegijapranata Semarang
}

\begin{abstract}
ABSTRAK
Bidan berperan penting dalam penurunan AKI/AKB, namun Permenkes No 1464 tahun 2010 mengurangi kewenangan praktik bidan mandiri. Timbul pertanyaan : bagaimanakah perlindungan hukum bagi bidan praktik mandiri dalam menghadapi kasus kegawatdaruratan, dan tuntutan masyarakat di daerah yang tidak terdapat dokter dalam memberikan pelayanan pengobatan umum, serta mensukseskan program keluarga berencana?

Penelitian ini menggunakan Metode Penelitian Yuridis Empiris dengan spesifikasi penelitian deskriptif analitis. Data empiris dilengkapi dengan data normatif akan dijadikan dasar di dalam memberikan identifkasi dan analisa yang menyeluruh mengenai bagaimana pelaksanaan kewenangan bidan terutama bidan praktik mandiri dan bidan praktik klinik bersalin di Kabupaten Tangerang dalam melakukan tindakan episiotomi yang diperluas pada proses persalinan normal per-vaginam dengan penyulit, serta bagaimana persetujuan tindakan medis (informed consent) dalam tindakan tersebut.

Ada pembatasan kewenangan praktik bidan yang cukup banyak pada Permenkes Nomor 1464 tahun 2010 dibanding dengan Kepmenkes Nomor 900 Tahun 2002, dan pada praktiknya bidan masih banyak yang menjalankan permenkes tersebut.
\end{abstract}

Kata kunci : Peran, kewenangan, bidan, kegawatdaruratan obstetri, episiotomi yangdiperluas, penjahitan luka jalan lahir. 


\section{PENDAHULUAN}

Pembangunan kesehatan telah menunjukan peningkatan status kesehatan masyarakat, ditandai dengan penurunan Angka Kematian Bayi (AKB) dari 46 per-1.000 kelahiran hidup tahun 1997 menjadi 34 per-1.000 kelahiran hidup tahun 2007 dan Angka Kematian Ibu (AKI) dari 318 per 100.000 kelahiran hidup tahun 1997 menjadi 228 per 100.000 kelahiran hidup tahun 2007 (SDKI, 2007)'. Kebijakan Departemen Kesehatan dalam upaya mempercepat penurunan AKI pada dasarnya mengacu kepada intervensi strategis "Empat Pilar Safe Motherhood" dan mengeluarkan kebijakan dengan mengupayakan agar setiap persalinan ditolong atau minimal didampingi oleh bidan serta pelayanan obstetri sedekat mungkin kepada semua ibu hamil ${ }^{2}$.

Peran penting bidan untuk menurunkan angka kesakitan dan kematian maternal dan perinatal sangat besar kontribusinya. Pelayanan kebidanan diberikan oleh bidan yang telah terdaftar (teregister) yang dapat dilakukan secara mandiri, kolaborasi atau rujukan sesuai Peraturan Menteri Kesehatan Nomor 1464/Menkes/Per/X/2010 Tentang Izin dan Penyelengaraan Praktik Bidan telah memberikan wewenang kepada bidan untuk melaksanakan tugasnya dengan baik dan profesional.

Permenkes No 1464 Tahun 2010 Pasal 10 ayat (2) menyebutkan bahwa kewenangan bidan dalam upaya pelayanan kesehatan ibu antara lain : "pelayanan antenatal pada kehamilan normal, pelayanan persalinan normal dan pelayanan ibu nifas normal", artinya kewenangan bidan pada kehamilan, persalinan dan nifas abnormal tidak diatur. Namun proses persalinan normal pervaginam tidak lepas dari penyulit yang dapat menyebabkan kematian ibu/janin, salah satu contoh kasus distosia bahu (shoulder dystocia) yang terkadang sulit diprediksi sebelumnya, menurut American College of Obstetrician and Gynecologist (2002) angka kejadian $0.6-1.4 \%$ dari persalinan normal ${ }^{3}$.

Akibat pembatasan kewenangan praktik bidan mandiri menimbulkan ketidaksinkronan Permenkes Nomor 1464 Tahun 2010 dengan Kepmenkes Nomor 369 Tahun 2007 yang memuat 9 kompetensi dan menimbulkan hak melakukan bagi bidan. Dan Permenkes nomor 1464 Tahun 2010 Pasal 3 butir (c) menyebutkan bidan berwenang memberikan pelayanan "penanganan kegawat-daruratan, dilanjutkan perujukan".

Berdasarkan kebijakan Departemen Kesehatan, bahwa "setiap persalinan ditolong atau minimal didampingi oleh bidan", maka peran bidan menjadi sentral, dan hal tersebut bertolak belakang dengan belum meratanya penempatan tenaga medis disetiap desa, maka proses pendampingan tenaga medis terhadap upaya pelayanan kesehatan yang dilakukan oleh bidan belum maksimal. Apakah hal ini masih terjadi di Kabupaten Tangerang yang notabene merupakan Kabupaten yang sudah maju dan dekat dengan Ibu Kota Jakarta, dimana bidan masih melakukan praktik diluar fungsinya menjalankan upaya pelayanan kesehatan kebidanan atau masih banyak kecamatan atau desa-desa di Kabupaten Tangerang yang belum ada tenaga dokter di Puskesmas Kecamatan atau dokter praktik swasta di wilayah kecamatan atau desa.

Bidan praktik swasta yang bertugas di fasilitas pelayanan kesehatan seperti di klinik bersalin, lebih dapat menjalankan kewenangan berdasarakan Permenkes Nomor 1464 Tahun 2010 karena bidan sebagai anggota team bersama tenaga medis yang mempunyai kewenangan ketika menghadapi penyulit persalinan normal pervaginam. Kompetensi yang dimiliki bidan di klinik bersalin dapat diaktualisasikan akibat pelimpahan wewenang dari tenaga medis, seperti yang terdapat dalam Peraturan Menteri Kesehatan Republik Indonesia Nomor

\footnotetext{
1 Depkes 2009, Sistim Kesehatan Nasional, Online, Internet, Diunduh 01-04-2012 http://www.depkes.go.id/downloads/SKN\%20final.pdf

2 Abdul Bari Saifuddin et all 2009, Buku Acuan Nasional Pelayanan Kesehatan Maternal Dan Neonatal, Ed. 1, Cet.5... Jakarta: PT Bina Pustaka Sarwono Prawirohardjo, hal 7.

3 American College of Obstetrician and Gynecologist (2002) Practice Bulletine no. 40 November 2002.
} 
512/MENKES/PER/IV/2007 Tentang Izin Praktik dan Pelaksanaan Praktik Kedokteran, yang untuk selanjutnya disebut sebagai Permenkes Nomor 512 Tahun 2007.

Dampak hukum pidana, perdata dan administratif akan timbul ketika bidan melakukan melakukan upaya kesehatan tidak sesuai kewenangan yang diberikan Permenkes Nomor 1464 Tahun 2010, padahal tuntutan masyarakat terhadap pelayanan bidan cukup besar dengan menganggap bidan merupakan tenaga kesehatan yang bisa melakukan segala hal yang berhubungan dengan kesehatan.

Hal yang perlu dilakukan oleh pemerintah dan organisasi profesi adalah sosialisasi peraturan kepada tenaga kesehatan dan masyarakat luas, serta pemerataan tenaga medis yang mempunyai kewenangan dalam pendampingan praktik bidan.

Berdasarkan uraian di atas, timbullah pertanyaan: bagaimana kewenangan hukum bidan dalam melakukan episiotomi yang diperluas sekaligus penjahitan luka jalan lahir ketika menghadapi kasus distosia bahu yang merupakan kegawatdaruratan kebidanan dan perbedaan pada bidan praktik mandiri dan klinik bersalin. Apakah ada perbedaan kewenangan bidan praktik mandiri dan praktik di klinik bersalin, serta tanggung jawab dokter pada klinik bersalin terhadap bidan?.

\section{PERMASALAHAN}

Dari latar belakang penelitian di atas, maka dirumuskan masalah penelitian yaitu: bagaimana ketentuan hukum bagi kewenangan bidan dalam melakukan tindakan episiotomi yang diperluas sekaligus penjahitan luka jalan lahir di praktek mandiri dan di praktek klinik bersalin pada persalinan normal per-vaginam dengan penyulit, dan implementasi kewenangan tersebut di Kabupaten Tangerang, serta tanggungjawab dokter sebagai pemberi delegasi terhadap bidan di klinik bersalin tanpa melakukan informed consent ?.

Dalam rangka menjawab perumusan masalah penelitian ini, maka digunakan metode penelitian deskriptif dengan pendekatan yuridis empiris dengan data normatif untuk kelengkapan dan akan dijadikan dasar di dalam memberikan identifkasi dan analisa yang menyeluruh mengenai bagaimana pelaksanaan kewenangan bidan praktik mandiri dan praktik klinik dalam melakukan tindakan episiotomi yang diperluas pada penyulit persalinan normal pervaginam. Atas dasar itulah, maka akan dilakukan analisis secara sistematis, kritis dan konstruktif untuk membangun sebuah konsep baru di dalam upaya memberikan perlindungan hukum bagi bidan dalam pelaksanaan tindakan episiotomi yang diperluasdan penjahitan luka jalan lahir.

\section{PEMBAHASAN}

a. Ketentuan hukum bagi peran kewenangan bidan dalam melakukan tindakan episiotomi yang diperluas, sekaligus penjahitan luka jalan lahir pada penyulit persalinan normal pervaginam di bidan praktik mandiri dan bidan praktik klinik bersalin.

Permenkes Nomor 1464 Tahun 2010 tidak mengatur kewenangan bidan dalam melakukan episiotomi yang luas/diperluas, hanya episiotomi dengan penjahitan luka jalan lahir tingkat I dan tingkat II. Namun bila bidan menghadapi kasus penyulit persalinan seperti distosia bahu yang merupakan kegawatdaruratan kebidanan, kewenangan tersebut bisa diberikan dengan tujuan penyelamatan nyawa ibu dan janin seperti pada Pasal 10 ayat (3) butir (c), dan sebagaimana disebutkan dalam Undang Undang Nomor 36 Tahun 2009 Pasal 32.

Pada bidan praktik mandiri, tanggungjawab hukum berada pada diri bidan sebagai tenaga kesehatan, ketika melakukan tindakan episiotomi yang diperluas atau diperluas dengan indikasi kegawatdaruratan dengan syarat bidan melakukan persetujuan tindak medis melalui informed consent, ada izin keluarga dan yang terpenting tidak ada dokter. Bila terdapat dokter pada bidan praktik mandiri, baik dokter yang bisa diminta bantuannya atau di klinik 
bersalin dengan penanggungjawab dokter maka kewenangan bidan dalam hal tersebut tidak berlaku dan harus dirujuk ke dokter. Tetapi tindakan tersebut dapat dilakukan bidan melalui delegasi atau pelimpahan wewenang dari dokter kepada bidan melalui suatu delegasi yang tertulis berdasakan Permenkes Nomor 512 Tahun 2007 Pasal 15.

Pelimpahan kewenangan medis kepada perawat harus tertulis dengan pertimbangan : 1) Dilindungi oleh aturan yang ada, 2) Merupakan bukti tertulis kewenangan mana yang boleh dilimpahkan sehingga dapat diketahui apabila terjadi perbuatan diluar kewenangan yang dilimpahkan bukan menjadi tanggung jawab pemberi kewenangan dan mutlak tanggung jawab yang diberi kewenangan, 3) Tidak semua kewenangan tindakan kedokteran dapat dilimpahkan kepada perawat/bidan, harus sesuai kemampuan profesionalnya.

Luka jalan lahir akibat dilakukan tindakan episiotomi yang luas atau diperluas bisa terjadi pada Tingkat III dan IV. Tingkat III : robekan mengenai perineum sampai dengan otot sfingter ani dan Tingkat IV : robekan mengenai perineum sampai dengan otot sfingter ani dan mukosa rektum. Memperbaiki luka jalan lahir Tingkat III dan IV tidak diberikan kepada bidan dan bidan harus segera mencari bantuan dengan sistem rujukan ke fasilitas pelayanan kesehatan yang ada dokter spesialisnya dengan alasan kompetensi bidan dalam penjahitan otot sfingter ani dan otot rektum.

b. Implementasi peran bidan dalam kewenangan melakukan tindakan episiotomi yang diperluas dan penjahitan luka jalan lahir pada bidan praktik mandiri dan bidan praktik di rumah bersalin di kabupaten tangerang.

Peran bidan di Kabupaten Tangerang yang melakukan praktik diberbagai tatanan pelayanan, termasuk di rumah secara mandiri, masyarakat, rumah sakit, klinik atau unit kesehatan lainnya seperti puskesmas dan sebagai bidan desa. Bidan dalam menjalankan praktik, berwenang untuk memberikan pelayanan yang meliputi : a. pelayanan kesehatan ibu, b. pelayanan kesehatan anak; dan c. pelayanan kesehatan reproduksi perempuan dan keluarga berencana.

Pada tempat bidan praktik mandiri di Kabupaten Tangerang, bidan masih sering melakukan praktik diluar kewenangan yaitu melakukan praktik mengobati penyakit umum seperti mengobati pasien laki-laki dewasa dengan berbagai penyakit dasar, bayi dan anak-anak yang menderita sakit yang sudah seharusnya menjadi wewenang dokter. Dari hasil pengamatan tempat praktik bidan didapatkan data bahwa tersedianya obat-obatan yang sama dijumpai pada praktik dokter seperti obat antibiotika, obat darah tinggi, obat jantung dan lain lain dan dari hasil wawancara terungkap alasan kuat bagi bidan dalam melakukan hal tersebut seperti pendapatan ekonomi bidan, kemauan pasien dan keluarga serta alasan tidak adanya dokter dan tetap merupakan pelanggaran hukum.

Hal yang menarik dari alasan bidan melakukan praktik non kebidanan karena permintaan pasien/keluarga menyebabkan peranan bidan menjadi lebih luas. Peranan bidan yang meluas ini berpotensi menimbulkan ${ }^{4}$ :

1. Konflik peran : bidan harus menjalankan peran yang tidak diharapkannya seperti mengobati orang sakit yang merupakan tugas dokter.

2. Ketegangan : terjadi apabila bidan mengalami kesulitan untuk melakukan peran sosial yang dimilikinya karena ada ketidaksesuaian antara kewajiban yang harus dijalankan dengan tujuan peran itu sendiri.

4 Alexandra Ide, 2012, Sosiologi Kebidanan, Cet 1 Rona Pancaran Ilmu, Yogyakarta. hal 117. 
3. Kegagalan peran : terjadi apabila bidan tidak sanggup menjalankan peran sekaligus karena keterbatasan-keterbatasan yang dimiliki bidan, sementara terdapat tuntutan-tuntutan lebih dari sekedar perannya sebagai bidan terkait kompetensi bidan dan tuntutan berlebihan dari masyarakat.

Permenkes Nomor 1464 Tahun 2010 Pasal 14 ayat (1) menyebutkan: "Bagi bidan yang menjalankan praktik di daerah yang tidak memiliki dokter, dapat melakukan pelayanan kesehatan di luar kewenangan sebagaimana dimaksud dalam Pasal 9". Dan ayat (2) menyebutkan; "Daerah yang tidak memiliki dokter sebagaimana dimaksud pada ayat (1) adalah kecamatan atau kelurahan/desa yang ditetapkan oleh kepala dinas kesehatan kabupaten/kota". Akan tetapi hal tersebut tidak ada penetapan dari Dinas Kesehatan Kabupaten Tangerang, walau pada praktiknya peneliti menemukan di daerah Kecamatan Kemiri tidak ada praktik dokter, yang ada hanya dokter di Puskesmas Kemiri dalam waktu jam dinas puskesmas. Dan apa yang dilakukan bidan praktik mandiri tetap merupakan pelanggaran hukum.

Pemerintah sebagai pemegang otoritas kekuasaan mempunyai tanggung jawab dalam pemenuhan hak setiap orang dalam memperoleh akses pelayanan kesehatan, seperti yang disebutkan pada UU Nomor 36 Tahun 2009 atas ketersediaan sumber daya di bidang kesehatan yang adil dan merata bagi seluruh masyarakat untuk memperoleh derajat kesehatan yangsetinggi-tingginya.

Pengetahuan bidan yang didapatkan dari hasil wawancara responden bidan tentang pertolongan persalinan dengan penyulit sangat memprihatinkan, terutama teknik melahirkan distosia bahu dimana tidak tahunya nama perasatnya. Menurut teori bisa dengan teknik atau perasat MC Robert dan sebelumnya dengan melakukan tindakan episiotomi secara luas dengan tujuan memperlebar jalan lahir.

Episiotomi adalah suatu tindakan insisi pada perineum yang menyebabkan terpotongnya selaput lendir vagina, cincin selaput dara, jaringan pada septum rekto vaginal, otot-otot dan fasia perineum dan kulit sebelah depan perineum ${ }^{5}$. Dari hasil wawancara, apakah episiotomi merupakan tindakan rutin tiap persalinan normal, dan apakah pernah melakukan terhadap pasien ibu bersalin?. Semua responden menjawab bukan tindakan rutin dan semua responden pernah melakukan episiotomi, dan semua menjawab memberitahu saat mau akan melakukan episiotomi ditandai dengan anggukan kepala pasien, tapi gak pernah secara tertulis.

Tindakan episiotomi merupakan tindakan bedah invasif dan menyebabkan tidak utuhnya jaringan tubuh, sudah selayaknya tenaga kesehatan medis bila ingin melakukan tindakan bedah memberitahukan kepada pasien. Pemberitahuan tersebut bisa dilakukan saat dalam proses persalinan atau sebelumnya dan segera dilakukan secara tertulis sesudah tindakan tersebut selesai. Begitu juga dalam penjahitan luka jalan lahir akibat robekan alamiah persalinan atau karena robekan episiotomi.

Hasil wawancara terhadap responden dalam pernah mengetahui tentang Permenkes No. 1464 Tahun 2010?. Dari semua responden tidak hafal nomor Permenkesnya, tapi pernah mendapat sosialisasi dari seminar di IBI Dan tanggapan bidan dan responden lain terhadap Permenkes No 1464 Tahun 2010 hampir semuanya mengatakan setuju dengan dikeluarkannya Permenkes tersebut dengan alasan yang semuanya hampir mirip yaitu pasrah terhadap peraturan yang ada dan menggarisbawahi pernyataan setuju tersebut dengan berharap pemerintah mendukung kebijakan tersebut dengan penyebaran tenaga medis lain ditempat bidan bertugas, yang lain mengungkapkan merupakan peraturan mau tidak mau harus

5 Hanifa Wiknjosastro, 1991, Ilmu Bedah Kebidanan, Cetakan kedua, Yayasan Bina Pustaka Sarwono Prawirohardjo, Jakarta, hal. 170. 
dilaksanankan, dan ada yang tidakmengerti Permenkes Nomro 1464 Tahun 2010 sebagai peraturan bidan. Bidan praktik mandirimasih menggunakan Kepmenkes 900/2002.

c. Tanggungjawab dokter sebagai penanggungjawab terhadap bidan di klinik bersalin, yang melakukan tindakan episiotomi yang diperluas melalui delegasi yang diberikan oleh dokter dan tanpa melakukan informed consent ?

Layanan kebidanan yang diberikan di klinik bersalin merupakan layanan kolaborasi, yaitu layanan yang dilakukan oleh bidan sebagai anggota team yang kegiatannya dilakukan secara bersamaan atau sebagai salah satu dari sebuah proses kegiatan pelayanan kesehatan, seperti disebutkan dalam Kepmenkes Nomor 369/MENKES/SK/III/2007 Tentang Standar Profesi Bidan. American Medical Assosiation (AMA), 1994, Kolaborasi adalah proses dimana dokter dan perawat merencanakan dan praktek bersama sebagai kolega, bekerja saling ketergantungan dalam batasan-batasan lingkup praktek mereka dengan berbagi nilai-nilai dan saling mengakui dan menghargai terhadap setiap orang yang berkontribusi untuk merawat individu, keluarga dan masyarakat ${ }^{6}$.

Tanggungjawab hukum bagi bidan di praktik Klinik Bersalin yang dijalankan sesuai dengan Permenkes Nomor 1464 Tahun 2010 adalah tetap menjadi tanggung jawab bidan itu sendiri. Tetapi bila bidan menjalankan praktik diluar kewenangan Permenkes tersebut, sesuai kompetensinya dan dilaksanakan melalui delegasi maka tanggungjawab hukum berada pada team yang terdiri dari dokter sebagai penanggungjawab klinik dan dokter yang memberikan pelimpahan wewenang/delegasi kepada bidan.

Landasan hukum yang mengatur pelimpahan wewenang dokter kepada tenaga keperawatan tertuang di Permenkes Nomor 512 Tahun 2007 Pasal 15, dimana dokter dapat melimpahkan wewenang kepada bidan sesuai kompetensinya dan dibutuhkan pada keadaan membutuhkan dan tidak ada dokter. Apabila bidan melakukan tindakan episiotomi yang diperluas serta penjahitan luka jalan lahir, maka pelimpahan wewenang ini menjadi tanggungjawab utama tetap ada pada dokter yang memberikan perintah, sedangkan bidan hanya mempunyai tanggungjawab sebagai pelaksana.

Pada praktiknya pelimpahan wewenang dokter kepada bidan di Rumah Bersalin Cikupa tidak pernah dilakukan secara tersurat, hanya tersirat melalui konsul secara langsung atau lewat telephone bila dokter tersebut tidak ada ditempat. Jadi surat limpah wewenang dokter kepada bidan tidak pernah ada di Rumah Bersalin ini, jadi ini merupakan pelanggaran hukum dan tanggung jawab hukum berada pada bidan yang melaksanakan bila tidak ada pertanggungjawaban dari yang memberi pelimpahan wewenang.

Tanggung Jawab hukum dokter yang menjadi penanggung jawab di Kilnik bersalin terhadap bidan yang melakukan tindakan episiotomi yang diperluas sekaligus penjahitan luka jalan lahir, terdiri dari: tanggung jawab administratif, perdata dan pidana.

Persetujuan tindakan medik harus diberikan pada setiap tindakan kedokteran yang akan dilakukan secara lisan atau tulisan dan setelah mendapat penjelasan cukup, dan ini teruang dalam Kepmenkes Nomor 290 Tahun 2008 Pasal 2. Pelimpahan kewenangan medis kepada perawat/bidan harus tertulis dengan pertimbangan : 1) Dilindungi oleh aturan yang ada, 2) Merupakan bukti tertulis kewenangan mana yang boleh dilimpahkan sehingga dapat diketahui apabila terjadi perbuatan diluar kewenangan yang dilimpahkan bukan menjadi tanggung jawab pemberi kewenangan dan mutlak tanggung jawab yang diberi kewenangan, 3) Tidak semua kewenangan tindakan kedokteran dapat dilimpahkan kepada perawat/bidan, harus sesuai kemampuan profesionalnya.

6 Internet www.nursingword.org/readroom, diunduh mei 2013. 


\section{PENUTUP}

Kewenangan bidan di praktik mandiri dan klinik bersalin untuk melakukan tindakan episiotomi yang diperluas, sekaligus penjahitan luka jalan lahir yang luas pada penyulit persalinan normal pervaginam tidak diatur. Pada Bidan Praktik Mandiri ketika berhadapan dengan kegawatdaruratan, maka bidan boleh melakukan tindakan diluar kewenangan demi menyelamatkan janin dan ibu dari kematian, dengan syarat harus ada persetujuan dari pasien dan keluarga, dan tidak ada dokter yang dimintai tolong atau dimintai konsul dalam melakukan tindakan tersebut. Hal ini tidak berlaku bagi bidan di klinik bersalin, dan kewenangan diperoleh melalui delegasi dari dokter.

Implementasi peran praktik bidan di Kabupaten Tangerang masih banyak ditemukan pelanggaran hukum, antara lain masih banyak ditemukan bidan yang berpraktik layaknya sebagai dokter dengan melakukan upaya kesehatan non-kebidanan, dengan alasan peningkatan ekonomi bidan, permintaan pasien dan keluarga serta masyarakat yang kurang mampu mengakses pelayanan kesehatan dari dokter akibat ketiadaan dokter praktik dan ekonomi masyarakat yang miskin. Di Kabupaten Tangerang belum ada kebijakan daerah dalam upaya mengatasi penyulit persalinan, sehingga ketika bidan menghadapi penyulit maka bidan tetap melakukan upaya kesehatan dengan melanggar hukum.

Kebijakan Nasional yang harusnya diikuti kebijakan daerah dalam mensukseskan Program Keluarga Berencana, tidak diikuti peran bidan praktik mandiri dalam memberikan metode Keluarga Berencana yang paling diminati akseptor KB adalah KB suntik, karena kewenangan suntik KB sudah tidak diatur atau dicabut dalam Permenkes Nomor 1464 Tahun 2010. Begitu juga dalam hal mensukseskan Program Imunisasi masal nampaknya juga menemui hambatan, karena bidan sudah tidak boleh memberikan imunisasi.

Bidan Praktik Mandiri dan Bidan di Klinik Bersalin belum seluruhnya menggunakan Permenkes Nomor 1464 Tahun 2010, dan IBI telah melakukan sosialisasi melalui pertemuan rutin setiap ranting dan cabang untuk membahas Permenkes ini dan bekerjasama dengan pihak terkait. Masalah pembinaan dan pengawasan dari otoritas yang berwenang terhadap praktik bidan belum berjalan dengan baik, meskipun UU dan peraturan mengharuskan pembinaan dan pengawasan dari pemerintah maupun organisasi profesi.

Tanggungjawab dokter sebagai penanggung jawab terhadap bidan di klinik bersalin, yang melakukan tindakan episiotomi yang diperluas serta penjahitan luka jalan lahir melalui delegasi dokter dan tanpa melakukan Informed Consent, dalam hal adanya pelimpahan wewenang ini tanggung jawab utama tetap ada pada dokter yang memberikan perintah, sedangkan bidan hanya mempunyai tanggung jawab sebagai pelaksana.

\section{DAFTAR PUSTAKA}

Depkes, 2008. Buku Acuan Pelatihan Klinik Asuhan Persalinan Normal, Asuhan Esensial, Pencegahan dan Penanggulangan Segera komplikasi Persalianan dan Bayi Baru Lahir, Revisi 5, Edisi 2008, Jakarta : Jaringan nasional pelatihan Klinik-Kesehatan Reproduksi.

Dinkes Kab Tangerang, 2010, Profil Kesehatan Kabupaten Tangerang, Tahun $2010 . \quad$ Tangerang: Dinas Kesehatan Kabupaten Tangerang.

Hanifiah, MJ. 2009. Etika Kedokteran dan Hukum Kesehatan Ed 4. EGC : Jakarta

Ide, A, Sosiologi Kebidanan, 2012, Cet 1- Oktober Yogyakarta : Rona Pancaran Ilmu.

Oxorn, H.et all. 2010, Human Labor And Birth, Ilmu Kebidanan : Patologi dan Fisiologi Persalinan, Editor: Mohammad Hakimi, Ed-1 Yogyakarta, Yayasan Essentia Medica, Andi Offset. 
Wiknjosastro, H, 1991. Ilmu Bedah Kebidanan, Ed.1. Cet ke-2, Jakarta : Yayasan Bina Pustaka Sarwono Prawirohardjo.

Widanti, A, et al, 2009. Petunjuk Penulisan Usulan Penelitian dan Thesis, Kesehatan, Semarang: Universitas Katolik Soegijapranata.

Magister Hukum

\section{PERATURAN PERUNDANG-UNDANGAN}

Undang-Undang Nomor. 36 Tahun 2009 Tentang Kesehatan

Undang-Undang Nomor. 44 Tahun 2009 Tentang Rumah Sakit

Undang-Undang Nomor. 29 Tahun 2004 Tentang Praktik Kedokteran

Peraturan Pemerintah Nomor 32 Tahun 1996 Tentang Tenaga Kesehatan

Peraturan Menteri Kesehatan Nomor 585/Men.Kes/Per/IX/1989 tentang Persetujuan Medik

Peraturan Menteri Kesehatan Nomor 900/MENKES/SK/VII/2002 Tentang Registrasi dan Praktik Bidan

Permenkes Nomor 290/Menkes/Per/III/2008 Tentang Persetujuan Tindakan Kedokteran

Peraturan Menteri Kesehatan Nomor 1464/MENKES/PER/X/2010, Tentang Izin dan Penyelenggaraan Praktik Bidan

Peraturan Menteri Kesehatan Nomor 028/MENKES/PER/I/2011 Tentang Klinik

Peraturan Menteri Kesehatan Republik Indonesia Nomor 1796/MENKES/PER/VII/2011 Tentang Registerasi Tenaga Kesehatan

Peraturan Menteri Kesehatan Nomor 2562/MENKES/PER/XII/2011 Tentang Petunjuk Teknis Jaminan persalinan (Jampersal)

\section{INTERNET}

American College of Obstetrician and Gynecologist (2002) Practice Bulletine no. 40 November 2002.

Depkes, 2009, Sistim Kesehatan Nasional 2009, http://www.depkes.go.id/ downloads/SKN\%2ofinal.pdf, Diunduh 01-04-2012.

Oxorn, H, 1998, Fifth Edition Human Labor and Birth, Copyright $\odot 1996$ - 1998 by Childbirth. org Allrights reserved. http://www.alibris.com/search/

books/qwork/3045219/used/Human\%20Labor\%20and\%20 Birth, Diunduh 14 April 2012. 